\title{
Masyarakat Madani Antara Semu dan Realita
}

\author{
Armyn Hasibuan \\ Fakultas Dakwah dan Ilmu Komunikasi IAIN Padangsidimpuan \\ (E-mail: armynhasibuan@gmail.com)
}

\begin{abstract}
This paper discusses the civil society be the goal of missionary activity in the present and future. This paper uses a literature review of books about the themes in the study . After a study found that the civil society to achieve the necessary awareness, willingness, readiness, unity and national partnership patriotic, religious, selfless solidarity or socialism. It is something that is difficult to reach, so, it's between realty and impossible but the first step has been started by the Prophet as a personal leader and manager.This is had ever exsist to example.
\end{abstract}

Keywords: Civil Society

Abstrak: Tulisan ini membahas tentang masyarakat madani yang menjadi tujuan dalam kegiatan dakwah pada masa sekarang dan akan datang. Tulisan ini menggunakan kajian literatur dari buku-buku yang berkenaan dengan tema kajian. Setelah dilakukan kajian mendapatkan bahwa untuk mencapai masyarakat madani diperlukan kesadaran, kemauan, kesediaan, kebersamaan dan kemitraan kebangsaan yang patriotis, religious, solidaritas atau sosialisme tanpa pamrih. Memang sesuatu yang sukar dicapai sampai orang mengatakan masyarakat madani antara semu dan realita, namun langkah awal telah dimulai oleh Rasulullah Saw sebagai pribadi yang leader dan manager.Tentu sesuatu yang telah pernah ada menjadi percontohan yang dapat ditiru dan diambil.

Kata Kunci: Masyarakat Madani. 
154 Armyn Hasibuan, Masyarakat Madani Antara Semu dan Realita Jurnal At-Taghyir : Jurnal Dakwah dan Pengembangan Masyarakat Desa Volume 1 Nomor 2 Juni 2019, h. 153-170

\section{A. Pendahuluan}

Masyarakat Jahiliah identik dengan masyarakat Barbar, dimana pemerintahan dan sistem manajemennya masih samraut dan belum ada penegakan hukum secara adil dan demokratis. Opposidenya adalah masyarakat madani (civil society) merupakan konsep filsafat yang dimunculkan oleh Aristoteles yang kemudian pemikirannya itu dikembangkan oleh Marcus Tullius Cicero, seorang filosof Rumawi Kuno (106-435 SM). Ia memunculkan istilah societies civilis dalam konsep negara kota untuk menggambarkan kerajaan kota dengan komunitasnya bentuk korporasi lainnya sebagai kesatuan yang terorganisir. ${ }^{1}$ Kemudian rumusan masyarakat madani (civil society) itu dikembangkan oleh Thomas Habbes (1588-1679 M) dan John Locke (1704 M). Menurut Habbes civil society sebagai konsep dan identitas negara untuk meredam konflik dalam masyarakat sehingga konsep itu harus memiliki kekuasaan mutlak dan mampu mengontrol dan mengawasi secara ketat pola-pola interaksi perilaku politik setiap warga negara. Sedangkan John Locke melihatnya sebagai konsep untuk melindungi kebebasan dan hak milik setiap warga negara.

Rumusan pemikiran kedua tokoh di atas menggambarkan perbedaan,dimana yang pertama menekankan harus adanya kepemerintahan yang sah dan manajemen yang baik, sementara yang kedua lebih melihat kebebasan dan diakuinya hak hak warga. Perkembangan pemikiran selanjutnya tidak ada absolulisme dan kekuasaan, hanya ada kebebasan dan sikap hidup yang toleran, baik antar anggota masyarakat maupun penguasa kepada warganya. ${ }^{2}$ Penyatuan antara kebebasan dan sikap hidup yang toleran, muncul di tengah elemen masyarakat secara menyeluruh baik masyarakat, birokrasi politik, advokasi, edukasi, dan rakyat jelata adalah merupakan sesuatu yang abstrak dan amat sukar terwujudkan untuk menjadi tatanan hidup bermasyarakat, berbangsa dan bernegara. Justru sebaliknya orang mengklaim bahwa prinsip masyarakat madani dewasa ini masih berada dalam pencarian, apalagi dalam mewujudkannya mungkin sesuatu yang masih angan-angan. Memang, masyarakat madani telah menjadi perhelatan baik di kalangan masyarakat, pemerintah dan akademisi mencoba bersama memikirkan bagaimana agar pembangunan kemakmuran rakyat di segala sektor dapat

\footnotetext{
${ }^{1}$ Adeng Mukhtar Ghazali, Civic Education, (Jakarta : Benang Merah Press, 2004), hlm. 107

2 ICCE, Demokrasi, Hak Asasi Manusia dan Masyarakat Madani, Cet II. (Jakarta: UIN Syarif Hidayatullah, 2006), hlm. 306
} 
155 Armyn Hasibuan, Masyarakat Madani Antara Semu dan Realita Jurnal At-Taghyir : Jurnal Dakwah dan Pengembangan Masyarakat Desa Volume 1 Nomor 2 Juni 2019, h. 153-170

terwujud sehingga kehidupan bermasyarakat dan bernegara semakin maju, damai, mandiri sejahtera dalam keadaan yang dilandasi iman dan ketakwaan. Pemerintah dan rakyatnya untuk saling terpanggil untuk saling menjaga persatuan dan kesatuan, menjungjung tinggi reformasi hukum menjaga harkat martabat anak bangsa secara struktural dan kultural.

Konsep masyarakat madani yang menyandang unsur-unsur dan konsep global tentang sistem pelaksanaan pengawasan, peraturan dan perundang-undangan yang berkeadilan dibidang ekonomi, politik, sosial budaya, pendidikan, toleransi dan perlindungan hak rakyat yang plural terus menjadi wacana di era globalisasi yang penuh reformasi dan keterbukaan ini. Akankah dapat terwujud atau setidaknya bagaimana kiat menuju tercapainya masyarakat madani?. Soalnya Apakah telah pernah ada masyarakat madani itu ? Dan bagaimana praktek kepemimpinan dan capaian nya sepanjang pengakuan orang lain sebagai salah satu tolok ukur? Jawaban yang sering diutarakan orang adalah masyarakat madani binaan Rasulullah SAW. dengan tolok ukur kepemimpinannya diakui orang lain,baik bangsa Yahudi di masanya mengadakan kerja sama dalam menciptakan masyarakat yang saling hormat menghormati meskipun berlaian ideology dan keyakinan, memiliki rakyat yaitu komunitas ansor dan muhajirin, memiliki undang undang yang ditaati oleh rakyat(umat) yaitu al Qur'an dan sunnah, memiliki tritorial daerah kekuasaan yaitu Madinatul munawwarah dan kepemimpinannya pro umat.

Secara realitas masyarakat madani itu ternyata telah pernah ada dan berhasil diakui oleh masyarakat internasional seperti yang dikatakan oleh seorang peneliti Inggris Michael H.Hart ${ }^{3}$ dalam bukunya Seratus Tokoh yang Paling Berpengaruh dalam Sejarah bahwa Muhammad SAW.adalah orangnmya sebagai pemimpin pertama dan manusia yang paling berpengaruh dalam sejarah manusia. Oleh karena itu memperbincangkan masyarakat madani merupakan suatu kepatutan meskipun sebagian orang berkata hal itu hanya sebatas nostalgia yang tidak mungkin terwujudkan. Tentunya suatu wacana dan konsep dalam menambahi wawasan pemikiran untuk lebih meningkatkan patriotisme kebangsaan masih batas legalitas tersajikan sebagai wacana ilmiah.

\footnotetext{
${ }^{3}$ Michael H.Hart, Seratus Tokoh Yang Paling Berpengaruh dalam Sejarah, (Jakarta: Pustaka Jaya, 1997), hlm. 34
} 
156 Armyn Hasibuan, Masyarakat Madani Antara Semu dan Realita Jurnal At-Taghyir : Jurnal Dakwah dan Pengembangan Masyarakat Desa Volume 1 Nomor 2 Juni 2019, h. 153-170

\section{B. Pengertian dan Ciri Masyarakat Madani}

Masyarakat madani terdiri dari dua suku kata masyarakat dan madani, masyarakat adalah sejumlah manusia dalam arti seluas luasnya dan terikat oleh suatu kebudayaan yang mereka anggap sama ${ }^{4}$. Madani berarti peradaban,sehingga bila dikatakan masyarakat madani dalam wacana ini merupakan konsep atau gagasan yang menggambarkan masyarakat beradab yang mengacu pada nilai-nilai kebajikan dengan mengembangkan dan menerapkan prinsip-prinsip interaksi sosial yang kondusif bagi penciptaan tatanan demokratis dalam kehidupan bermasyarakat dan bernegara. Disisi lain, masyarakat madani diartikan sebagai masyarakat yang beradab, menjungjung tinggi nilai-nilai kemanusiaan, maju dalam penguasaan ilmu pengetahuan dan teknologi. ${ }^{5}$ Masyarakat beradab adalah masyarakat manusia yang berpendidikan, sopan dan berbudaya. Peradaban mereka meliputi keseluruhan kompleksitas produk pikiran kelompok mereka yang mengatasi negara, ras, suku atau agama yang membedakan dari yang lain. Peradaban memiliki nilai-nilai yang dijunjung tinggi bersama sebagai suatu sistem yang mengikat meskipun tidak tertulis secara yuridis formal.

Masyarakat madani sebagai masyarakat yang memiliki keunggulan dapat dilihat dari ciri-cirinya hampir mencakup kesempurnaan. Menurut Deny Suito bahwa masyarakat madani yang dimaksud bercirikan antara lain:

1. Terintegrasinya individu-individu dan kelompok-kelompok eksklusif ke dalam masyarakat melalui kontrak sosial dan aliansi sosial.

2. Menyebarkan kekuasaan sehingga kepentingan-kepentingan yang mendominasi dalam masyarakat dapat dikurangi oleh kekuatan-kekuatan alternatif.

3. Dilengkapinya program-program pembangunan yang didominasi oleh negara dengan program-program pembangunan yang berbasis masyarakat.

4. Terjembataninya kepentingan-kepentingan individu dan negara karena keanggotaan organisasi volunter mampu memberikan masukan-masukan terhadap keputusankeputusan pemerintah.

5. Tumbuh-kembangnya kreativitas yang pada mulanya terhambat oleh rezim-rezim totaliter.

\footnotetext{
${ }^{4}$ Depdikbud. Kamus Besar Bahasa Indonesia, (Jakarta: Balai Pustaka, 1995), hlm. 635

5 Abdullah Syamsuddin, Agama dan Masyarakat, (Jakarta: Logos Wacana Ilmu, 1997), hlm. 38
} 
157 Armyn Hasibuan, Masyarakat Madani Antara Semu dan Realita Jurnal At-Taghyir : Jurnal Dakwah dan Pengembangan Masyarakat Desa Volume 1 Nomor 2 Juni 2019, h. 153-170

6. Meluasnya kesetiaan (loyalty) dan kepercayaan (trust) sehingga individu-individu mengakui keterkaitannya dengan orang lain dan tidak mementingkan diri sendiri.

7. Adanya kebebasan masyarakat melalui kegiatan lembaga-lembaga sosial dengan berbagai ragam perspektif.

8. Bertuhan, artinya bahwa masyarakat tersebut adalah masyarakat yang beragama, yang mengakui adanya tuhan dan menempatkan hukum tuhan sebagai landasan yang mengatur kehidupan sosial.

9. Damai, artinya masing-masing elemen masyarakat, baik secara individu maupun kelompok menghormati pihak lain secara adil.

10. Tolong-menolong tanpa mencampuri urusan internal individu lain yang dapat mengurangi kebebasannya.

11. Toleran, artinya tidak mencampuri urusan pribadi pihak lain yang telah diberikan oleh Allah sebagai kebebasan manusia dan tidak merasa terganggu oleh aktivitas pihak lain yang berbeda tersebut.

12. Keseimbangan antara hak dan kewajiban sosial.

13. Berperadaban tinggi, artinya bahwa masyarakat tersebut memiliki kecintaan terhadap ilmu pengetahuan dan memanfaatkan kemajuan ilmu pengetahuan untuk ilmu pengetahuan manusia.

14. Berakhlak mulia. ${ }^{6}$

Sebagian pakar menyederhanakan ciri masyarakat madani itu dengan menyebut krakter khusus masyarakat madani yaitu antara lain : wilayah public yang bebas, demokrasi, toleransi, pluralism dan keadilan sosial ${ }^{7}$. Melihat ciri-ciri di atas menggambarkan bahwa masyarakat madani itu, penuh program pembangunan berbasis masyarakat, tumbuh dan berkembangnya loyalitas kesetiakawanan penuh kebersamaan merwujudkan keadilan, keseimbangan antara hak dan kewajiban rakyat sebagai bagian dari masyarakat itu sendiri. Disinilah kemapanan seorang leader ( pemimpin ) ditagih untuk sekaligus menjadi manager dalam pengembangannya sebagai orang nomor satu,

\footnotetext{
${ }^{6}$ Deni Suito, Membangun Masyarakat Madani, (Jakarta: Centre For Moderate Muslim, 1999), hlm. 87

7 A. Ubaedillah \& Abdul Rozak, Pancasila, Demokrasi, HAM dan Masyarakat Madani, (Jakarta: ICCE UIN Syarif Hidayatullah, 2012), hlm. 225
} 
158 Armyn Hasibuan, Masyarakat Madani Antara Semu dan Realita Jurnal At-Taghyir : Jurnal Dakwah dan Pengembangan Masyarakat Desa Volume 1 Nomor 2 Juni 2019, h. 153-170

artinya kemampuan inteligen question dan kompetensi kompetensi lainnya harus dapat lebih produktif untuk yang dipimpin.

Toleransi melekat pada keperibadian umat, bangsa yahudi dan nasrani dapat hidup berdampingan bahkan memiliki jaminan keselamatan dalam kepemerintahan rasul di madinah,mereka memiliki peradaban yang tinggi saling menghormati tidak saling mencacimaki menebar hoak berita bohong. Masyarakat beradab mengembangkan tatanan demokratis, rukun damai, cinta sains dan teknologi, betapa gigihnya para sahabat nabi menggali ilmu dari rasul berkat motivasinya bahwa orang belajar,berilmulah yang tahu Tuhan,dapat berakhlak mulia yang dilandasi dengan keberagamaan dan kemanusiaan yang setiap saat diaplikasikan mereka baik sebagai umat biasa, pemerintah dan elemen masyarakat secara struktural maupun struktural.

\section{Deskripsi Al-Qur'an tentang Masyarakat Madani}

1. Masyarakat Saba'

Meskipun al-Qur'an bukan kitab tata negara dan undang-undang bernegara, tetapi secara analisis konseptual al-Qur'an menggambarkan Saba' sebagai negeri yang baik di kiri-kanannya, disebutkan dua buah ladang sebagai lambang kemakmuran yang membuat masyarakatnya makmur yang berimbas rukun, damai, saling toleransi dan saling menghargai satu dengan yang lainnya, hidup tenang, bahagia, loyalitas dan patriotisme yang tinggi dari masyarakat kepada pemimpin meskipun seorang wanita yang bernama Balqis. Allah Swt berfirman dalam al-Qur'an surah Saba' ayat 15:

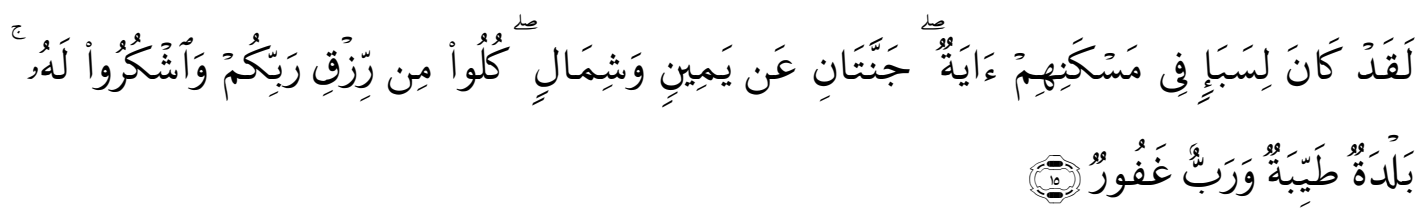

'Sesungguhnya bagi kaum Saba' ada tanda (kekuasaan Tuhan) di tempat kediaman mereka Yaitu dua buah kebun di sebelah kanan dan di sebelah kiri. (kepada mereka dikatakan): "Makanlah olehmu dari rezki yang (dianugerahkan) Tuhanmu dan bersyukurlah kamu kepada-Nya. (Negerimu) adalah negeri yang baik dan (Tuhanmu) adalah Tuhan yang Maha Pengampun". (QS, Saba': 15)

Berdasarkan pengetian ayat di atas, dijelaskan masyarakat Saba' mempunyai territorial (wilayah) yang cukup luas memiliki masyarakat yang dipimpin oleh ratu

\footnotetext{
${ }^{8}$ Depqag R.I, Al Qur'an dan Tarjamahnya, (Semarang: Toha Putra, 1998), hlm. 685
} 
159 Armyn Hasibuan, Masyarakat Madani Antara Semu dan Realita Jurnal At-Taghyir : Jurnal Dakwah dan Pengembangan Masyarakat Desa Volume 1 Nomor 2 Juni 2019, h. 153-170

Balqis, memiliki kepemimpinan yang ditaati oleh rakyatnya, memiliki perundangundangan serta diakui oleh inteligen Nabi Sulaiman as. sehingga dalam teori sederhana Saba' merupakan suatu negeri yang telah pernah ada dan diklasifikasikan masyarakatnya sebagai masyarakat madani. Meskipun ratu Balqis baru memiliki agama naturalisme mempercayai benda-benda alam seperti matahari yang dipandang memiliki kekuatan gaib, berimplikasi menggiring rakyatnya menyembah matahari agar kekuatan gaib dapat membantu mereka dalam bermasyarakat penuh damai, bahagia, makmur dan satu kesatuan tanpa malapetaka dan bencana alam. Maka persembahan ritual ibadahpun dilakukan secara serentak dan priodik antara pihak kerajaan (Balqis) dengan elemen masyarakat, mereka betul betul menyatu antara pemimpin dengan rakyat. Hal ini dapat diamati dan dilaporkan oleh mata-mata inteligen Nabi Sulaiman as. yaitu burung HudHud.

Salah satu yang menarik dari gambaran wahyu Allah Swt lewat firmannya yang menginformasikan itu adalah mereka sebagai masyarakat Saba' masih disuruh untuk menikmati, memakan hasil-hasil kebun sebagai lambang kemakmuran dan kemapanan pangan meskipun masyarakat menyembah matahari bahkan dinyatakan negeri yang baik, wajar mereka masih menyembah matahari karena dakwah rasul belum ada dan tidak sampai, maka Tuhan Maha Pemurah. Menurut analisis penulis, kemakmuran negeri merupakan dasar utama yang akan dapat menggiring rakyat berkeadilan, bermasyarakat, beragama dan bertuhan. Ketika datang dakwah kepada mereka, pesanpesan dakwah atau ajaran agama akan lebih mudah dipertimbangkan dan diterima manakala keperluan material dan tingkat ekonomi mereka telah cukup terpenuhi. Hal itu terbukti ketika Balqis ditemui oleh Nabi Sulaiman as. dan disampaikan dakwah dan ajaran monoteisme alias tauhid, dengan mudah dan logis dia dan rakyatnya menerimanya, karena cukup tenang, kenyang dan dapat berpikir maksimal secara positif tentang ide, arahan dan manfaat dari suatu ajaran.

Orang miskin melarat lagi lapar akan lebih sukar diarahkan untuk berakhlak mulia dan beradab bahkan mereka akan saling menghantam, bunuh membunuh dan cekal mencekal. Pikiran mereka tertumpu bagaimana memenuhi keperluan dasar, sandang,pangan dan papan sebagai ukuran kehidupan primitive yang paling rendah, apalagi menjadikan mereka masyarakat madani yang indikator serta ciri-cirinya 
160 Armyn Hasibuan, Masyarakat Madani Antara Semu dan Realita Jurnal At-Taghyir : Jurnal Dakwah dan Pengembangan Masyarakat Desa Volume 1 Nomor 2 Juni 2019, h. 153-170

mendekati kesempurnaan,terasa mustahil. Justru itulah sabda Rasulullah Saw menyatakan "...Kemiskinan hampir saja menjadikan manusia menjadi kufur". Kekufuran akibat kemiskinan ketertinggalan dan kebodohan sumber daya manusianya mengakibatkan pelanggaran-pelanggaran diberbagai bidang termasuk ajaran Tuhan akhirnya jauh dari akhlak yang baik,bencana bertubi tubi akan menimpa.

Sebaliknya, manakala umat atau rakyat suatu Negara taat pada perintah Allah, masih ditemui penegakan hukum dan pelaksanaannya secara efektif dan efesien, adil dan penuh ubudiyah, maka Tuhan masih akan memalingkan bencana alam ke tempat lain yang keranjingan dengan perilaku mesum dan maksiat yang meraja lela.

2. Masyarakat Madinah

Meskipun masyarakat Madinah sebagian digambarkan sebagai kaum munafik, sebagaimana dalam surah at-Taubah ayat 101, tetapi setelah Muhammad Saw. memimpin mereka yang dimulai sejak beliau hijrah dari Makkah ke Madinah tahun pertama hijriyah (622 M). Jumlah pengikutnya mulai bertambah sehingga beliau perlu meletakkan dasar-dasar masyarakat Islam, ${ }^{9}$ yang pada gilirannya digambarkan secara gamblang pada ayat yang lain sebagai berikut ini:

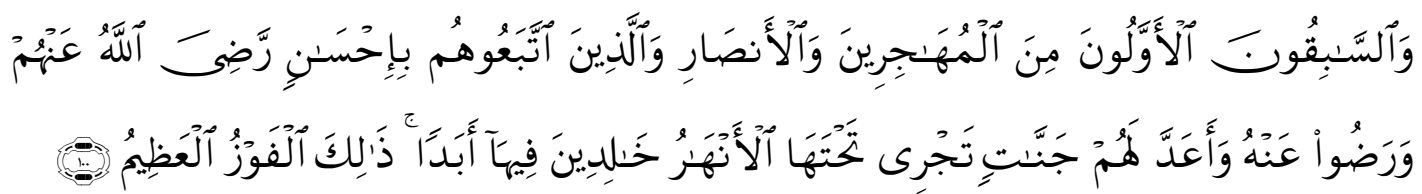

"Orang-orang yang terdahulu lagi yang pertama-tama (masuk Islam) dari golongan muhajirin dan anshar dan orang-orang yang mengikuti mereka dengan baik, Allah ridha kepada mereka dan merekapun ridha kepada Allah dan Allah menyediakan bagi mereka surga-surga yang mengalir sungai-sungai di dalamnya selama-lamanya. mereka kekal di dalamnya. Itulah kemenangan yang besar. (QS, At-Taubah: 100) ${ }^{10}$

Dari ayat di atas dipahami bahwa masyarakat Madinah yang terdiri dari kamu Muhajirin dan kaum Anshar mendapat sanjungan Allah Swt dengan keridhaan-Nya disebabkan mereka pernah menjadi komunitas yang beriman, setia kepada Rasulullah Saw. sebagai pimpinan dan saling tolong menolong membentuk masyarakat damai di atas multi etnis dengan agama Allah dan peraturan yang digagas bersama Rasulullah

\footnotetext{
${ }^{9}$ Ira M. Lapidus, Sejarah Sosial Umat Islam, (Jakarta: Rajawali Pres, 1996), hlm. 112

${ }^{10}$ Depag R.I., Al-Qur'an dan Tarjamahnya, Op.Cit., hlm. 297
} 
161 Armyn Hasibuan, Masyarakat Madani Antara Semu dan Realita Jurnal At-Taghyir : Jurnal Dakwah dan Pengembangan Masyarakat Desa Volume 1 Nomor 2 Juni 2019, h. 153-170

Saw.sama ditaati dan di jungjung tinggi, sehingga tidak tajam ke bawah tumpul ke atas, tetapi tajam selama lamanya artinya berlaku untuk semua strata masyarakat. Mayoritas penduduk Madinah terutama suku Auz dan Khazraj menyambut baik ajaran Nabi Muhammad Saw. menyatakan kesetiaannya kepada Nabi Saw. dan bersedia membantu beliau menyebarkan Islam. Kedatangan Rasulullah Saw. di Madinah bukan merebut kekuasaan dan kebesaran, tetapi akan memberikan pimpinan yang sebaik-baiknya. Langkah pertama yang beliau lakukan adalah membangun masjid sambil gotong royong mempersaudarakan antara kaum Anshar dan Muhajirin.

Masjid dibangun bukan sekedar tempat untuk melaksanakan shalat semata, tetapi juga merupakan sekolah dan tempat bimbingan, balai pertemuan, tempat mempersatukan berbagai unsur kekabilahan dan sisa-sisa pengaruh perselisihan semasa jahiliyah. Ira M. Lapidus menggambarkan bahwa "Islam prophet particularly effective in unifying tribal societies and motivating militant strangle in the interest of the religious community as a whole"11. Islam terbukti efektif dalam penyatuan masyarakat keseluruhan dan dalam hal kelompok militan dari kepentingan komunitas keagamaan secara menyeluruh. Kemudian salah satu pernyataan Rasulullah Saw. kepada para sahabatnya bahwa sebaik-baik manusia adalah kamu (sahabat) yang hidup di kurunku. Hal ini menggambarkan masyarakat Madinah adalah masyarakat yang telah memiliki nilai plus, baik deberbagai aspek apa sajapun seperti persatuan dan kesatuan,toleransi, tasamuh dan kerjasama menangkal bahaya yang diperkirakan datang dari luar . Prinsip sederhana berdirinya suatu negara ketika itu telah dimiliki Rasulullah Saw yaitu adanya teritorial, masyarakat, hukum perundang-undangan dan diakui bangsa atau suku lain (dalam hal ini bangsa yahudi bani Musthalik, Quraizah, Nadhir dan lainnya). Madinah juga mengadakan kerjasama (MOU) dengan suku atau bangsa lain. Semuanya telah terwujud saat Rasulullah Saw. di Madinah saat menjadi kepala agama sekaligus kepala negara. Beliau menjadi pemimpin dan teladan masyarakat yang disenangi, disegani dan dihormati di tengah masyarakatnya yang heterogen.

\footnotetext{
${ }^{11}$ Ira M. Lapidus, Op.Cit., hlm. 115
} 
162 Armyn Hasibuan, Masyarakat Madani Antara Semu dan Realita Jurnal At-Taghyir : Jurnal Dakwah dan Pengembangan Masyarakat Desa Volume 1 Nomor 2 Juni 2019, h. 153-170

\section{Analisis Terhadap Masyarakat Binaan Rasulullah Saw}

1. Pemimpin dan yang Dipimpin

Memperhatikan rumusan Kuncoro Ningrat menjelaskan bahwa elemen terkecil syarat terwujudnya suatu masyarakat adalah:

a. Beranggotakan minimal dua orang

b. Anggotanya sadar sebagai suatu kesatuan.

c. Berhubungan dalam waktu yang cukup lama yang menghasilkan manusia baru yang saling berkomunikasi dan membuat aturan-aturan hubungan antara anggota masyarakat.

d. Menjadi sistem hidup bersama yang menimbulkan kebudayaan serta keterkaitan satu sama lain sebagai anggota masyarakat. ${ }^{12}$

Nabi Muhammad Saw. pemimpin memiliki kompetensi di atas seorang leader dan manajer. Seorang leader adalah pemimpin yang mampu mengarahkan orang agar suka dan mau berkerja sesuai tujuan suatu organisasi. Manajer pun demikian bahkan lebih luas fungsinya, Widiyanti menjelaskan cakupannya sebagai berikut:
a. Merencanakan (planning)
b. Mengorganisasi (organizing)
c. Mengarahkan (actuating)
d. Mengawasi (controlling) ${ }^{13}$

Masyarakat Madinah yang heterogen beliau sebut sebagai Anshar yang berarti penolong dan mereka yang datang dari Mekkah sebagai Muhajirin (pendatang) yang dipersatukan dengan ukhuwah Islamiah. Keahliannya membangun negara dengan mengatakan bahwa kaum Muhajirin dan Anshar sama-sama mempunyai tanggung jawab dalam membangun masyarakat, menghadapi kesukaran dan serangan dari luar. Beliau mengikat kedua golongan dengan sekuat-kuatnya bersama prinsip-prinsip mempunyai kelompok yang banyak demikian juga dengan orang Yahudi Bani Musthalih, Quraizah, Nadhir dan Qaimaq sehingga tidak ada perbedaan dalam membela negara. Banyak tulisan sejarah yang menggambarkan bahwa Nabi Muhammad Saw sebagai pemimpin dan para sahabatnya hidup dengan ukhuwah Islamiah yang kental,

\footnotetext{
${ }^{12}$ Kuncoro Ningrat, Antropologi Sosial (Bandung: Pustaka Jaya, 1990), hlm. 156

13 Y.W. Sumindhia dan Nini Widiyanti, Kepemimpinan dalam Masyarakat Modern, (Jakarta:
} PT. Prima Jaya, 1988), hlm. 10 
163 Armyn Hasibuan, Masyarakat Madani Antara Semu dan Realita Jurnal At-Taghyir : Jurnal Dakwah dan Pengembangan Masyarakat Desa Volume 1 Nomor 2 Juni 2019, h. 153-170

saling menyayangi diantara mereka, saling membela dan saling menolong sesamannya. Di dalam surah Al-Fath digambarkan mereka hidup saling-tolong menolong satu dengan yang lainnya, bekerja keras, bergotong royong, beribadah dan mencari ridha Allah Swt.

2. Undang-Undang dan Penegakan Hukum

Kepemimpinan Rasulullah Saw di Madinah bukan saja sebagai pemimpin agama, tetapi juga menjadi pemimpin negara. Setelah berhasil menciptakan masyarakat baru dengan menciptakan kesatuan akidah, politik, dan sistem kehidupan di antara orang-orang muslim, beliau merasa perlu mengatur hubungan dengan selain umat Islam. Perhatiannya terpusat menciptakan keamanan, ketentraman, kedamaian, kebahagiaan dan kebaikan bagi semua manusia. Maka untuk ini beliau pun menetapkan undangundang penuh tenggang rasa. Undang-undang yang dituangkan dalam piagam Madinah disusun oleh ilmuan muslim dan non muslim ketika itu, diakui bersama dan ditaati bersama secara umum. ${ }^{14}$

Keautentikan piagam itu dapat dilihat dari aspek muatan, bahasa, dan uslubnya. Muatannya menggambarkan komposisi atau sosiologis penduduk Madinah yang multi etnis, suku dan agama. Keasliannya tercermin pada uslub redaksinya. Teksnya terdiri dari kalimat-kalimat pendek, banyak pengulangan di tulis dalam satu pola yaitu penggunaan kata-kata dan ungkapan yang sesuai dengan waktu itu menggambarkan semangat zaman. Sayuti Pulungan menganalisis bahwa lahirnya piagam Madinah merupakan perbuatan Nabi sendiri ${ }^{15}$ yakni hadis sahih dilihat dari segi rawinya. Ia termasuk dalam kategori hadis masyhur yang tidak dipermasalahkan.

Al-Qur'an dan hadis menjadi dasar hukum dan diterjemahkan serta diimplementasikan dalam kehidupan bermasyarakat, bernegara dengan membangun umat. Hukum bukan tajam ke bawah dan tumpul ke atas, tetapi tajam secara merata, adil dan bermartabat. Di dalam salah satu statemen Rasulullah Saw beliau menyatakan: “...Kiranya Fatimah binti Rasul mencuri niscaya akulah yang memotong tangannya...". Dipahami dengan itu bahwa penerapan hukum adalah sama, yang harus ditaati dan berlaku pada seluruh elemen masyarakat Madinah. Persekongkolan hukum

\footnotetext{
${ }^{14}$ W. Moutgomery Watt, Muhammad and Madena (London: Oxford University Press, 1972), hlm. 225

15 Syayuti Pulungan, Prinsip prinsip Pemerintahan dalam Piagam Madinah ditinjau dari Pandangan al-Qur'an, (Jakarta; Rajawali Press, 2005), hlm. 105
} 
164 Armyn Hasibuan, Masyarakat Madani Antara Semu dan Realita Jurnal At-Taghyir : Jurnal Dakwah dan Pengembangan Masyarakat Desa Volume 1 Nomor 2 Juni 2019, h. 153-170

sehingga terjadi kolusi,nepotisme dan penyelewengan kolektif adalah akibat tidak diberdayakannya hukum secara merata. Penerapan hukum dapat ditelusuri betapa rasul memberlakukannya sama dengan dengan orang muslim,tidak pilih buluh dan adil dalam pelaksanaannya. Yahudi dapat merasa aman dan damai ditengah kehidupan umat islam sebagai seorang kafir zimmy yang mendapat jaminan perlindungan secara formal. 3. Sains dan Politik

Menurut penulis Islam sebagai agama sekaligus melahirkan sains yaitu pengetahuan secara umum yang problemanya menggunakan logika konseptual dan praktis. Banyak firman Allah Swt yang menyuruh orang beriman agar selalu menggunakan akal pikirannya bahkan orang yang dapat mengintegrasikan pikiran dengan zikirnya sehingga ia sadar akan keagungan Tuhan mendapat julukan Ulul Al$B a b$. Biasanya orang yang telah sampai memperoleh ulul al-bab manakala taraf berpikirnya sampai pada kode etik keIslaman yang salah satunya dapat berpikir sehat dan netral serta berada dalam posisi konseptor, motivator,kominikator sekaligus cerdas dan politikus. Sains sebagai ilmu adalah netral dia dapat dimiliki siapa saja yang menginginkannya. Menurut Imam Al-Ghazali, ilmu apa saja amat ditentukan orang yang memilikinya ${ }^{16}$, artinya penggunaan suatu ilmu pengetahuan sangat terserah kepada pemiliknya. Demikian juga hasil dari sains berupa teknologi dapat membantu dan meringankan beban manusia dan dapat juga membumi-hanguskan manusia. Di sinilah pentingnya iman dan takwa (imtak) mendampingi teknologi itu sendiri. Kekuatan semangat menuntut ilmu dan mengamalkannya yang selalu rasul sampaikan kepada sahabatnya bahwa seorang alim (ilmuan) jauh lebih baik enampuluh kali lipat dari pada seorang a'bid (ritus tanpa ilmu) memiliki nilai filosofis pentingnya ilmu pengetahuan bagi kehidupan manusia.

Kemodernan terindikasi bahwa rasul serahkan kepada sahabat dimana beliau mengatakan : Kamu lebih tahu tentang keduniaanmu yakni perkembangan modernitas. Ketika itu sahabat telah sampai pada kegiatan pencangkokan suatu kurma yang lebih berbuah dikawinkan dengan kurma yang baik pula agar menghasilkan produksi yang melimpah. Berarti teknologi modern akan dapat digunakan kepada kemanusiaan oleh hamba-hamba Allah Swt bahkan harus diikuti kemajuannya demi menunjang

\footnotetext{
${ }^{16}$ Imam al Ghazali, Ihyah Ulumuddin, (Beirut: Al Maktabah, 1398), hlm. 201
} 
165 Armyn Hasibuan, Masyarakat Madani Antara Semu dan Realita Jurnal At-Taghyir : Jurnal Dakwah dan Pengembangan Masyarakat Desa Volume 1 Nomor 2 Juni 2019, h. 153-170

kemaslahatan dan kemajuan umat. Ulama adalah gelar keilmuan yang sudah professional bukan saja di bidang keagamaan melainkan secara universal,ia harus mengetahui politik yang dilandasi ilmu dan ketakwaan sehingga bagaimanapun keberhasilan sains dan teknologi dan perjalanan politik, ia sadar semuanya adalah alat untuk menambahi pengabdian yang harus semakin soleh,baik soleh individual maupun kesalehan sosial. Ulama model inilah yang selalu menegakkan dan memperjuangkan bagaimana masyarakat tetap dalam keseimbangan hidup antara kemajuan fisik material dan spiritual. Militansinya lebih berani ketimbang ulama su' yang orientasinya materi dunia belaka.

Politik atau siasah merupakan alat untuk meraih tujuan, rasul dan para sahabatnya telah berhasil membangun masyarakat dengan politik, agama islam mempraktekkan politik demi tujuan agama, bukan mempolitikkan agama demi tujuan pribadi, partai atau tujuan bisnis. Cobalah perhatikan indahnya ajaran agama dalam mengajari umat memenangkan agamanya sendiri dari orang non muslim yang ingin menghancurkan islam seperti ungkapan al-Qur'an yang mengatakan "Tidak ada paksaan dalam agama", orang yang non muslim akan terhapus segala dosa dan kesalahannya manakala ia masuk Islam. Ungkapan al-Qur'an "tidak ada paksaan dalam agama". bukan berarti ketika seorang muallaf (orang yang baru masuk Islam) mengucapkan dua kalimat syahadat, lalu ia kebal dosa sepanjang masa, lalupun dia bebas-sebebasnya melakukan maksiat dan kejahatan lainnya, tentu tidak!. Agama itu sendiri memaksannya untuk melakukan rangkaian-rangkaian fardhu ain, kifayah dan kewajiban kolektifnya dengan orang lain sebagai makhluk zoon politicon yakni makhluk bermasyarakat, baik kewajiban membangun dan membela negara berarti ia tetap dipaksa, meskipun yang memaksanya adalah ajaran agama itu sendiri bukan orang, di sinilah kompetensi diri yang harus dibarengi dengan ilmu dan kesadaran diri untuk bergerak berbuat yang terbaik.

Orang non muslim akan terhapus segala dosanya manakala ia masuk Islam, di dalam kalimat tersebut terkandung nilai politik agama, agar dia sendiri masuk dan melihat serta membandingkan ajaran agamanya dengan ajaran agama penutup dan penyempurna ini dari semua aspek kemanusian, logis atau doktrin, perlu dicontoh atau ditakuti lalu dimusuhi dan disingkirkan. Ajaran Tuhan tetap eksis dan menjadi petunjuk, 
166 Armyn Hasibuan, Masyarakat Madani Antara Semu dan Realita Jurnal At-Taghyir : Jurnal Dakwah dan Pengembangan Masyarakat Desa Volume 1 Nomor 2 Juni 2019, h. 153-170

pedoman, dan hukum mewujudkan peradaban manusia meskipun pada hakikatnya Tuhan tidak akan rugi dan beruntung manakala seluruh manusia menjadi kufur dan jahat, baik buruknya seseorang hanya untuk peribadinya sendiri dan sedikit buat orang lain.

4. Membangun Masyarakat Berbasis Dakwah

a. Pembinaan Pendidikan

Masyarakat dalam tatanan kenegaraan memiliki tujuan aklamasi bersama akan hidup di bawah panji-panji pemerintahan yang demokratis dan memperjuangkan kemajuan negara, masyarakat dan bangsa. Konsep itu hendaknya diwujudkan dari berbagai undang-undang, peraturan pemerintah atau dengan program, prinsip dan instruksi lainnya. Pendidikan adalah suatu sektor yang signifikan meskipun prosesnya agak pelan tetapi dampak positifnya dapat menimbulkan perubahan kebiasaan jelek dan budaya yang kurang etis, menjadi baik menuju yang diidam-idamkan. Pendidikan bukan tanggung jawab perorangan atau orangtua saja, melainkan juga tanggung jawab pemerintah dan negara ${ }^{17}$. Oleh karenanya pengadaan dan penyusunan kurikulum amat menentukan arah kemana anak didik akan dibawa. Patriotisme dan humanisme dapat diajarkan bagi anak-anak didik lewat pembenahan pendidikan dengan pengadaan, penentuan dan arah kurikulumnya.Sudah saatnya mengadakan kajian penselarasan kurikulum dengan apa sumberdaya alam yang mendesak untuk dikelola dari suatu daerah, jangan hanya menjadi konsumen tetapi berangkatlah menjadi produsen,kelola alam lingkungan yang kaya sumber daya alamnya.

Kemudian yang tidak kalah pentingnya adalah lapangan kerja sebagai jawaban dari keluhan para sarjana yang telah selesai dari perkuliahannya, menginginkan kesempatan kerja yang baik dan sesuai dengan skillnya masing-masing. Tingkat pendidikan yang baik akan memudahkan mereka diterima di suatu lembaga atau perkantoran.Merekadi motivasi menjadi pencipta lapangan kerja bukan mundar mandir mencari kerja bagaikan pengemis berdasi, mereka di ciptakan yang beretika,bermoral dan berakhlak.

${ }^{17}$ BP7., Materi Penataran P-4 750 jam Disampaikan oleh Ka Kanwil Depagsu, 1994 
167 Armyn Hasibuan, Masyarakat Madani Antara Semu dan Realita Jurnal At-Taghyir : Jurnal Dakwah dan Pengembangan Masyarakat Desa Volume 1 Nomor 2 Juni 2019, h. 153-170

b. Dakwah Struktural dan Kultural

Membangun masyarakat madani tidaklah mudah, mungkin saja terbentang di benak kita suatu yang mustahil. Tetapi dalam teori ilahiyah hal itu bisa saja terwujud, manakala manusia itu sendiri secara mayoritas berkeinginan dan berkemauan. Dakwah struktural adalah aktivitas pemerintah atau negara dengan berbagai strukturnya dalam membangun masyarakat agar sesuai dengan petunjuk Allah Swt dan sunah Rasulullah Saw dalam bingkai amar ma'ruf nahi munkar. ${ }^{18}$ Sementara dakwah struktural adalah dakwah yang berbentuk penanaman nilai-nilai Islam dalam seluruh dimensi kehidupan. Memperhatikan potensi dan kecenderungan manusia sebagai mahluk budaya secara luas, dalam tujuan mewujudkan masyarakat Islam berakhlak. ${ }^{19}$ Kedua substansi dakwah di atas menjadi tulang punggung dan ujung tombak dari proses dakwah itu sendiri. Keduanya mungkin amat sukar diraih karena kehidupan secara de facto lebih banyak dipenuhi sekularisme dan globalisasi yang lebih mengedepankan westernisasi. Semangat mengedepankan kebaikan meskipun tidak melalui jalur pemerintahan dengan berbagai struktur lembaga dan Islamisasi budaya, merupakan ciri dan upaya dakwah sebagimana dicontohkan oleh Rasulullah Saw. Gilirannya elemen masyarakat tokoh dan para pemimpinnya akan merindukan dan menginginkan kebenaran dan kesalehan sendiri pada saatnya tiba.

"Mulailah dari dirimu..." demikian pengakuan dari sepotong hadis Nabi Muhammad Saw kebenaran bernilai tinggi dan ada saatnya dicari. Kenapa penulis lebih mendahulukan dakwah struktural daripada dakwah kultural? Jawabannya karena penulis melihat pemerintah yang secara yuridis formal, kebijakan pemerintah lebih berkompeten dan tepat lakonnya bilamana merekalah pelaku dakwah awal. Ulama, tokoh adat dan tokoh masyarakat lainnya akan lebih mudah mengikuti manakala diarahkan dan diperintahkan oleh pemerintah atau negara. Justru perwujudan konsep di atas haruslah dimulai oleh rakyat. Saat pesta demokrasi dan sosialisasi kampanye para pemimpin digelar, selayaknya rakyat selektif dalam menentukan pemimpin yang layak dengan melihat sisi kepribadian, karakter, kebiasaan, akhlak dan sifat sosial yang sesuai dengan ajaran Islam. Orientasi yang sama harus diwujudkan memiliki figure pemimpin

\footnotetext{
${ }^{18}$ Ramli Ridwan, Pemberdayaan ekonomi Umat Melalui Dakwah Struktural, (Jakarta: Rajawali Pres, 2004), hlm. 146

${ }^{19}$ PPM., Dakwah Kultural Muhammadiyah, (Yogyakarta: Suara Muhammadiyah, 2004), hlm. 26
} 
168 Armyn Hasibuan, Masyarakat Madani Antara Semu dan Realita Jurnal At-Taghyir : Jurnal Dakwah dan Pengembangan Masyarakat Desa Volume 1 Nomor 2 Juni 2019, h. 153-170

yang beriman, bertakwa, memiliki manajerial, kognitif, kebangsaan, kepemimpinan dan sosial yang baik perlu pengkaderan yang lebih intensif. Sebab mencari dan menemukan calon pemimpin yang demikian masih susah dan membutuhkan waktu yang lama. Apalagi pengaruh materialisme dan globalisasi menjadikan seseorang mudah berubah, beralih dan terkadang peralihan dan perubahan itu sudah melewati batas-batas yang ditentukan oleh ajaran Islam.

Realitasnya, media dalam memberikan pencitraan tentang figur pemimpin masih cenderung materialis dengan tujuan keuntungan dari iklan kampanye para calon pemimpin. Kenyataannya figur seseorang yang dicitrakan media cenderung dilebihlebihkan tidak sesuai dengan kenyataan pada jati diri seorang calon pemimpin tersebut. Jadilah penyebar kebaikan, ciptakanlah suasana indah, menyenangkan kepada semua orang di atas koridor yang legal.

c. Motivasi Ganda

Meskipun berbuat baik itu boleh dipamerkan, dengan catatan agar kebaikan itu dapat dicontoh orang lain, apabila hanya untuk sebatas popularitas semata, konsep akhlak tasawuf menyatakan amal tersebut adalah riya' sehingga tidak memiliki nilai pahala di sisi Allah Swt. Masyarakat yang bercita-cita menjadi masyarakat madani maka hendaknya setiap orang yang berbuat baik bangga akan kebaikan yang pernah ia raih dan dicapainya, dengan catatan tidak bercampur unsur sombong di dalamnya. Sebaliknya setiap orang juga harus merasa malu, jera dan menyesal apabila ia telah melakukan tindak kejahatan, amoral, kezaliman dan maksiat, sehingga peluang taubat dari dosa-dosa yang telah diperbuat terbuka dengan lebar. Koruptor sebagai salah satu contoh tindakan yang tidak sesuai dengan ajaran Islam kiranya dapat menjadi contoh bagi masyarakat agar termotivasi menjadi jujur dan adil. Penulis berpendapat hal itu dapat diwujudkan manakala memperbanyak motivasi ganda berupa prestasi dengan penghargaan material, jabatan, kedudukan, dan sumber kehidupan yang dapat menganggkat seseorang yang memiliki skill dan kemampuan. Baik untuk jangka waktu yang tidak terbatas, demikian juga motivasi berupa prestise yang terus dihargai bukan hanya dalam waktu sesaat saja, tetapi dijadikan teladan bagi generasi mendatang. Kembali kita buka lembaran sejarah Islam, kenapa keilmuan berkembang di zaman Abbasiyah? Karena negara sangat menghargai keilmuan maupun skill yang dimiliki 
169 Armyn Hasibuan, Masyarakat Madani Antara Semu dan Realita Jurnal At-Taghyir : Jurnal Dakwah dan Pengembangan Masyarakat Desa Volume 1 Nomor 2 Juni 2019, h. 153-170

siapa saja. Karya keilmuan menjadi ikon percontohan yang melahirkan motivasi berbuat baik demi kemajuan bagi masyarakat, negara dan bangsa. Menghargai karya, skill dan profesionalitas akan mengangkat harkat dan martabat suatu bangsa berindikasi maju, damai, toleransi, makmur dan bahagia. Sekali menanam, memberi hasil selamanya atau setidaknya memberikan manfaat untuk seluruhnya, layaknya rahmat bagi seluruh alam.

\section{E. Penutup}

Masyarakat madani telah pernah ada jauh sebelum masa nabi Muhammad SAW.membangun masyarakat madani yang terletak di kota Madinah Arab Saudi yang kemudian menjadi acuan bagi orang yang ingin mencontoh atau mengadopsinya di masanya untuk menciptakan masyarakat madani yang lebih elok. Diawali dengan kesadaran, kemauan, kesediaan, kebersamaan dan kemitraan kebangsaan yang patriotis, religious, solidaritas atau sosialisme tanpa pamrih. Memang sesuatu yang sukar dicapai, namun langkah awal telah dimulai oleh Rasulullah Saw sebagai pribadi yang leader dan manager. Masyarakat madani adalah masyarakat yang hidup aman ,damai, hidup dalam plural suku dan bangsa,saling hormat menghormati, tasamuh ,tidak saling menghujat apalagi membuat berita hoak. Dakwah struktural dapat dimulai dari pemerintah untuk memberdayakan lembaga struktural sampai ke bawah terlibat sebagai dai dan menjadi pencetus kebaikan, keadilan dan kebersamaan bagi pribadi untuk pribadi, dan rakyat yang dipimpin. Pemerintah lebih berwibawa apabila merangkul ulama, tokoh masyarakat lainnya untuk membangun moral, etika, akhlak sebagai jati diri bangsa. Seluruh lapisan masyarakat pun dapat memulai dengan memilih calon pemimpin yang akuntabel di bidang manajerial keilmuan, kenegaraan, kepedulian rakyat dan memiliki wawasan luas membangun untuk generasi ke depan. Dakwah struktural dan kultural menyatu menjadi kompetensi diri dari setiap anak bangsa yang secara perlahan merasa malu apabila melakukan penipuan, penyelewengan, korupsi, dan tindakan amoral serta mampu menghormati karya dan kelebihan orang lain. 
170 Armyn Hasibuan, Masyarakat Madani Antara Semu dan Realita Jurnal At-Taghyir : Jurnal Dakwah dan Pengembangan Masyarakat Desa Volume 1 Nomor 2 Juni 2019, h. 153-170

\section{Daftar Kepustakaan}

Abdullah Syamsuddin, Agama dan Masyarakat, Jakarta: Logos Wacana Ilmu, 1997.

Adeng Mukhtar Ghazali, Civic Education, Jakarta: Benang Merah Press, 2004.

Deny Suito, Membangun Masyarakat Madani, Jakarta: Centre For Moderate Muslim, 1999.

Departemen Agama RI, Al-Qur'an dan Terjemahnya, Semarang: Toha Putra, 1998.

ICCE, Demokrasi, Hak Asasi Manusia, dan Masyarakat Madani, Cet. II, Jakarta: UIN Syarif Hidayatullah, 2006.

Imam Al-Ghazali, Ihya Ulumuddin, Beirut: Al-Maktah, 1398.

Ira M. Lapidus, Sejarah Sosial Umat Islam, Jakarta: Rajawali Press, 1996.

Kuncoro Ningrat, Antropologi Sosial, Bandung: Pustaka Jaya, 1990.

PPM, Dakwah Kultural Muhammadiyah, Yogakarta: Suara Muhammadiyah, 2004.

Ramli Ridwan, Pemberdayaan Ekonomi Umat melalui Dakwah Struktural

Ja'far Puteh Saifullah, Dakwah Tekstual dan Konseptual; Peran dan Fungsinya dalam Pemberadaan Ekonomi Umat, Yogyakarta, Ak-Group, 2006.

Sayuti Pulungan, Prinsip-Prinsip Pemerintahan dalam Piagam Madinah ditinjau dari Pandangan Al-Qur'an, Jakarta: Rajawali Press, 2005.

W. Moutgomery Watt, Muhammad at Madena, London: Oxford University Press, 1972.

Y.W.Sumindhia dan Nini Widiyanti, Kepemimpinan dalam Masyarakat Modern Jakarta : PT.Prima Jaya,1988. 